\title{
A singularidade da
cinquentenária Placar
para o contexto histórico do
jornalismo esportivo no Brasil
}

\author{
DANIEL LEAL \\ Doutorando \\ Universidade Federal de Pernambuco/Rede Nordestina \\ de Estudos em Mídia e Esporte \\ Brazil \\ danielleal87@gmail.com
}

Giovana Borges Mesquita

Professora

UFPE

Grupo Dinâmicas do Jornalismo Brazil

giovanamesquita@yahoo.com.br

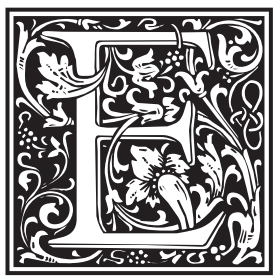

m março de 2020, a Placar, mais longeva revista esportiva do país, completou meio século de história no jornalismo esportivo brasileiro. Cinco décadas de uma vida, mas muitas faces (Unzelte, 2015), permeadas por diferentes perfis editoriais, administrações, transações, encerramentos e ressurgimentos, em distintas fases.

Apontada por diversos autores com um dos mais importantes veículos de imprensa esportiva brasileira (Ribeiro, 2007; Saldanha, 2009), "se não o principal" (Malaia, 2012:149), a Placar atravessou diversas gerações de torcedores brasileiros e contribuiu para construir no imaginário desses fãs uma série de reflexões que vão desde a combinação "política e futebol" (Schatz, 2015; Malaia, 2012) até as discussões acerca da necessidade de modernização do esporte mais popular do país (Saldanha, 2009). Ademais, na quase intermitente luta pela sobrevivência no mercado, o periódico também precisou reinventar-se como produto jornalístico e a modernizar a si própria através de mudanças de perfis (dentre os quais destacamos a Placar Todos os Esportes, Placar Mais, Futebol, Sexo e Rock \& Roll e a Placar Caras) que acompanharam a evolução social com novas noticiabilidades (Leal, 2020).

A revista notabilizou-se, por exemplo, por seções tradicionais nas suas páginas, como: "Tabelão", "Tira-teima", "Mortos-vivos", "Resumão"4 "Numeralha", dentre outros. Em 1995, ao trazer uma das suas fases mais emblemáticas, a Futebol, Sexo e Rock \& Roll, che-

Pour citer cet article, to quote this article, para citar este artigo :

Daniel Leal, Giovana Borges Mesquita « A singularidade da cinquentenária Placar para o contexto histórico do jornalismo esportivo no Brasil », Sur le journalisme, About journalism, Sobre jornalismo [En ligne, online], Vol 10, n² - 2021, 15 décembre december 15 - 15 de dezembro.

URL : https://doi.org/10.25200/SLJ.v10.n2.2021.443 
gou a marca de meio milhão de exemplares vendidos em uma única edição (Ribeiro, 2007).

Por se tratar de uma referência nacional, a Placar já foi alvo de vários estudos (Saldanha, 2009; Unzelte, 2015; Malaia, 2012; Schatz, 2015; Leal, 2020). A partir desta realidade, o desafio maior da construção deste artigo é trazer à luz uma nova contribuição à comunidade científica, especialmente ao campo da comunicação esportiva.

Dentro desse contexto, o nosso objetivo aqui é oferecer uma reflexão acerca da importância da revista Placar para a construção do jornalismo esportivo no Brasil, fazendo uma sistematização das diferentes fases e distintos momentos do periódico. Para isso, pretendemos responder à seguinte questão-problema: de que forma a revista Placar contribuiu para o fortalecimento da mídia esportiva no Brasil?

Para a construção do artigo, além do levantamento bibliográfico, fomos a campo para entrevistar jornalistas que compuseram as equipes do periódico em diferentes momentos, para discutir o legado jornalístico da Placar tentar reconstruir, respeitando os limites espaciais deste artigo, as nuances que envolveram os 50 anos da sua trajetória.

\section{METODOLOGiA}

Para a construção deste artigo, buscamos fazer uma imersão na construção teórica e historiográfica da principal revista especialista em esportes no Brasil. Este estudo constitui uma revisão bibliográfica de caráter analítico (Thomas; Nelson, 1996) sobre a evolução que constituiu a Placar, em meio século de vida, como referência do jornalismo esportivo no Brasil. O caminho para a resposta nos levou a percorrer meio século de história.

Fizemos entrevistas, entre os dias 27 de agosto e 3 de setembro de 2019, na cidade de São Paulo, com sete jornalistas que passaram pela Placar: Juca Kfouri, “o mais icônico ex-diretor da revista” (Placar, ed.1457:4), Ricardo Corrêa, Celso Unzelte, Marcelo Duarte, Maurício Barros, Paulo Vinícius Coelho e Sérgio Xavier Filho.

Todas as entrevistas foram realizadas individualmente, em locais e horários pré-agendados, conforme desejado pelas fontes. Nossa única exigência foi que os diálogos ocorressem de maneira presencial por entendermos que a comunicação não-verbal também contribui com "manifestações de comportamento não expressas por palavras, como os gestos, expressões faciais, orientações do corpo, as posturas (...)" (Silva et al., 2000:53).

Optamos pela entrevista individual em profundidade, "um recurso metodológico que busca, com base em teorias e pressupostos definidos pelo investigador, recolher respostas a partir da experiência subjetiva de uma fonte, selecionada por deter informações que se deseja conhecer" (Duarte, 2010:62). De acordo com o autor, esse tipo de conversação busca maior intensida-

Tabela 1 - Jornalistas entrevistados para esta pesquisa

\begin{tabular}{|c|c|c|c|}
\hline Entrevistados & Período na Placar & Função exercida na Placar & Cargo em 2019 \\
\hline Celso Unzelte & $\begin{array}{l}1990 \text { a } 1991 ; \\
1997 \text { a } 2000 ; 2015\end{array}$ & $\begin{array}{l}\text { Estagiário, repórter, editor, editor espe- } \\
\text { cial e editor-chefe }\end{array}$ & $\begin{array}{l}\text { Comentarista ESPN e professor } \\
\text { universitário }\end{array}$ \\
\hline Juca Kfouri & $\begin{array}{l}1970 \text { a } 1978 \\
1978 \text { a } 1995\end{array}$ & $\begin{array}{l}\text { Arquivista, supervisor e gerente do De- } \\
\text { partamento de documentação; chefe de } \\
\text { reportagem, editor e diretor de redação }\end{array}$ & $\begin{array}{l}\text { Blogueiro do UOL, colunista da } \\
\text { Folha de São Paulo e comentarista } \\
\text { da Rádio CBN }\end{array}$ \\
\hline Marcelo Duarte & $\begin{array}{l}1984 \text { a } 1989 ; \\
1995 \text { a } 1998\end{array}$ & $\begin{array}{l}\text { Assistente de redação, repórter, repórter } \\
\text { especial, editor, editor especial e chefe } \\
\text { de redação }\end{array}$ & $\begin{array}{l}\text { Escritor e diretor editorial da edito- } \\
\text { ra Panda Books }\end{array}$ \\
\hline Maurício Barros & 2002 a 2014 & Editor e chefe de redação & Comentarista ESPN \\
\hline $\begin{array}{l}\text { Paulo Vinícius } \\
\text { Coelho (PVC) }\end{array}$ & 1991 a $1997 ; 2000$ & Estagiário, repórter, editor & Blogueiro do UOL \\
\hline Ricardo Corrêa & $\begin{array}{l}1981 \text { a } 2005 \\
2012 \text { a } 2019\end{array}$ & $\begin{array}{l}\text { Estagiário, fotógrafo, editor de fotogra- } \\
\text { fia, editor-chefe }\end{array}$ & Editor chefe da Placar \\
\hline $\begin{array}{l}\text { Sérgio Xavier } \\
\text { Filho }\end{array}$ & 1995 a 2015 & $\begin{array}{l}\text { Editor sênior, chefe de redação e diretor } \\
\text { de redação }\end{array}$ & $\begin{array}{l}\text { Comentarista da TV Globo/Spor- } \\
\text { TV }\end{array}$ \\
\hline
\end{tabular}

Fonte: do autor (2021) 
de nas respostas, não quantificação ou representação estatística - exatamente a nossa intenção.

Um aspecto importante levado em consideração durante os procedimentos metodológicos foi a particularidade de entrevistar especialistas em tal ação, os jornalistas. Temer e Tuzzo (2017: 460) defendem dois pontos distintos: os jornalistas tendem "a não serem bons entrevistados"; por outro lado, por trabalharem com informação e atuarem como mediadores entre a informação e o público, esses profissionais tendem a visualizar suas recordações de forma diferenciadas.

Broustau et al. (2012:17) observam que "o pesquisador deve encontrar as modalidades adequadas para ter acesso à fala de um jornalista que se situa, nesse momento e da mesma forma que outras categorias de respondentes, em uma postura invertida com relação às suas interações tradicionais". Os jornalistas, embora em uma posição de entrevistado, também conhecem as sutilezas dessa prática, o que lhes permitem antecipar, às vezes de forma considerável, as respostas esperadas, ou pretensamente esperadas (Broustau et al., 2012).

A par disso, precisamos ficar atentos às armadilhas impostas pelo memorialismo e/ou aspectos afetivos dos entrevistados, extraindo deles os "fatos", mas sem deixar de lado nossas interpretações acerca deles. Além disso, o cruzamento de informações com as pes- quisas bibliográficas foi crucial para atestar ou confrontar a veracidade dos depoimentos orais, que, em linhas gerais, permitiram-nos identificar e preencher lacunas relacionadas às escolhas editoriais, aos ciclos e às formas de exercer o jornalismo na Placar. "O ponto central da realização de entrevistas é justamente o de atribuir novamente às falas geradas o status de dados a serem desconstruídos e analisados" (Broustau et al., 2012:17).

A partir dessa base, apresentaremos como a Placar se tornou um expoente referencial para todos os profissionais da área no país, com reportagens esportivas históricas, e como a revista precisou se reinventar diante das novas tecnologias e, principalmente, lutar ao longo de sua trajetória, de forma recorrente, contra problemas financeiros - como, a propósito, faz até hoje. Assim, nem mais tão firme e forte, mas tradicionalíssima, mantém-se como um patrimônio vivo, documento histórico do jornalismo esportivo brasileiro.

\section{PlaCAR: UMA LONGa GeSTAÇÃo}

Multicolorida, novidade para a época, a revista Placar revolucionaria o noticiário esportivo nacional pelas reportagens de impacto, criatividade, longevidade e, por que não dizer, polêmicas. Não tardaria para obter grande êxito e logo se tornar concorrente direto do Jornal dos Sports ${ }^{6}$. Foi de lá, inclusive, de onde fez

Tabela 2 - A evolução histórica da revista Placar em 50 anos

\begin{tabular}{|c|c|c|c|}
\hline Fase da revista & Período & Periodicidade & Editora \\
\hline Fase inaugural & 1970 a 1984 (ed. 1 a 725$)$ & Semanal & Editora Abril \\
\hline Placar Todos os Esportes & Entre de abril e novembro de 1984 (ed. 726 a 755) & Semanal & Editora Abril \\
\hline Sem fase temática & 1984 a $1988 .($ ed. 756 a 951$)$ & Semanal & Editora Abril \\
\hline Placar Mais & Setembro de 1988 a abril de 1989 (ed. 952 a 982) & Semanal & Editora Abril \\
\hline Sem fase temática & Maio de 1989 a agosto de 1990 (ed. 983 a 1051) & Semanal & Editora Abril \\
\hline $\begin{array}{l}\text { Fase Especial } \\
\text { (pós-encerramento) }\end{array}$ & Outubro de 1990 a março de 1995 (ed. 1052 a 1101) & Mensal & Editora Abril \\
\hline Futebol, Sexo e Rock \& Roll & Abril de 1995 a fevereiro de 1999 (ed. 1102 a 1148) & Mensal & Editora Abril \\
\hline Sem fase temática & Março de 1999 a março de 2001 (ed. 1149 a 1173) & Mensal & Editora Abril \\
\hline Placar Semanal & Abril de 2001 a fevereiro de 2002 (ed. 1174 a 1219) & Semanal & Editora Abril \\
\hline Sem fase temática & Março de 2002 a junho de 2015 (ed. 1220 a 1403) & Mensal & Editora Abril \\
\hline Placar Caras & Julho de 2015 a setembro de 2016 (ed. 1404 a 1418) & Mensal & Editora Caras \\
\hline Sem fase temática & Outubro de 2016 a dezembro de 2019 (ed.1419 a 1458) & Mensal & Editora Abril \\
\hline
\end{tabular}

Fonte: do autor (2021) 
migrar boa parte dos profissionais que iriam compor seu time, incluindo nomes como, por exemplo, o do cartunista Henfil.

Nascia forte, fruto da Editora Abril, aquela que é apontada por Ribeiro (2007:208) como "a maior e melhor revista esportiva do Brasil (...), destinada a leitores interessados em reportagens mais elaboradas, inteligentes, escritas por feras do jornalismo esportivo". De acordo com o autor, logo na primeira edição, a revista teria vendido 500 mil exemplares, versão contrariada por Chiarioni e Kroehn (2010), que apontam uma tiragem de 120 mil. Seja como for, Placar nasceu forte. Talvez, fruto de uma gestação demasiada grande, esticada por duas décadas.

Unzelte (2015) aponta que entre 1950 e 1960, a Abril já tinha uma série de títulos importantes. Capricho (1952) e Ilusão (1958) eram revistas com fotonovelas voltadas para o público jovem do sexo feminino. Cláudia (1961) destinava-se às mulheres casadas. Realidade (1966), mensal, e Veja (1968), semanal de informação, também faziam parte do time. Faltava um projeto que abraçasse os esportes. Em 1952, a Seleção Brasileira, dois anos após perder o título mundial no Maracanã para o Uruguai no fatídico Maracanazzo, foi campeã pan-americano de futebol. Seria ainda quinto lugar na Olimpíada de Helsinque, no mesmo ano. Lá, Ademar Ferreira da Silva voltaria com a medalha de ouro no salto triplo.

Com esse cenário, afirma Gonçalo Junior (2005), o jornalista Cláudio de Souza, que quase vinte anos depois viria a ser o primeiro editor da Placar, sugeriu a Victor Civita, fundador do Grupo Abril, a criação de uma revista esportiva. Deu até o nome que hoje tão bem conhecemos. O chefe gostou da proposta, como diria na "Carta do Editor" na edição 1 da Placar, mas engavetou-a.

Ainda em caráter experimental, a Abril lançou seis edições da revista, entre 3 de fevereiro e 13 de março. Com a repercussão positiva, ela foi oficializada em 20 de março de 1970: com 40 páginas de $31 \mathrm{~cm}$ de altura por $23 \mathrm{~cm}$ de largura. O lançamento da Placar, revista semanal, aconteceu dias depois da publicação do Decreto-Lei $\mathrm{n}^{\circ} 1.077$, assinado pelo presidente (e ditador) Emílio Garrastazu Médici. Tal decreto legalizava a censura prévia. Embora o periódico tivesse como objeto o esporte, e o futebol como carro-chefe, o assunto interessava ao governo do período (Malaia, 2012; Schatz, 2015).

É neste contexto que a revista assume a áurea daquela que iria se tornar uma de suas marcas mais relevantes: a veia jornalística de combate. "Desde os primeiros números, podem-se notar na revista reportagens cujo teor se chocava com as diretrizes governa- mentais dadas à imprensa" (Malaia, 2012:154). O autor cita alguns exemplos para justificar a afirmativa, mas nenhum caso é tão relevante quanto o que envolveu o ex-técnico da Seleção João Saldanha.

Membro do Partido Comunista Brasileiro (PCB), Saldanha já era famoso pelo seu trabalho como comentarista esportivo quando chegou à Seleção em 1969. Nesta altura, era sabidamente um sujeito polêmico. E não admitia interferência no seu trabalho. Patrícia Schatz (2015) observa que Placar fornece elementos essenciais para a análise da presença militar na comissão técnica da Seleção. Apaixonado por futebol, e com a estratégia de usar o esporte como meio populista, Médici queria interferir na escalação do atacante Dario, do Atlético-MG. Foi desse atrito que surgiu a clássica frase de Saldanha: "Ele escala o Ministério e eu escalo a Seleção”.

Figura 1 - Edição número 1 da Placar com Pelé na capa

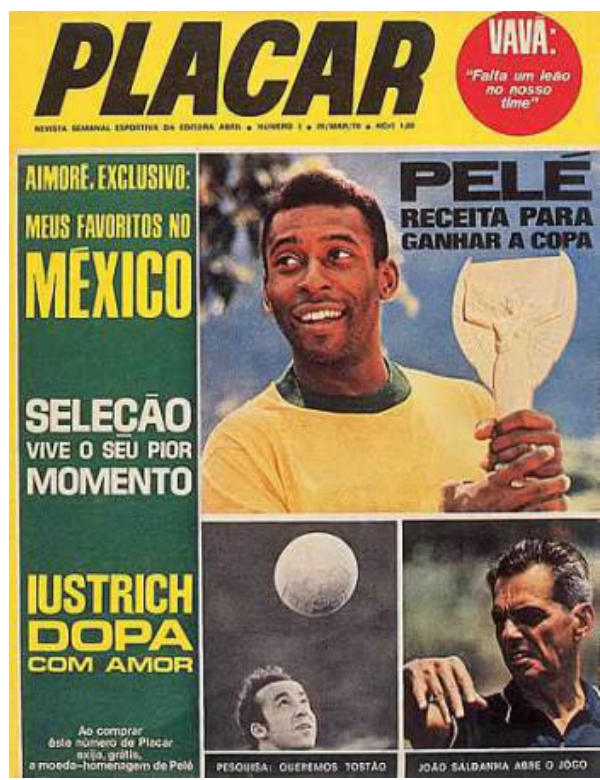

Fonte: Revista Placar/Reprodução

Acumulando outras controvérsias, inclusive envolvendo Pelé ${ }^{8}$, o técnico foi demitido. Na sua edição $\mathrm{n}^{\circ} 1$, Placar trouxe, na página 2, a matéria "A crise $d a$ fera", destacando o conflito e as polêmicas envolvendo o antigo técnico. Na mesma edição, na página $5, \mathrm{Ha}-$ milton Almeida, um dos editores do periódico, escreveu a crônica "João-Quixote". O texto aponta o futebol brasileiro como um "circo", compara cartolas a "mágicos" e "engolidores de tochas" e diz que é em João “em quem menos cabe nessa hora a colorida roupa de palhaço", pois "melhor do que palhaço, você é domador". Ao fim, faz uma crítica velada à interferência política no futebol.

Essa briga é maior, mais importante e digna de um João-Quixote puro, líder e síntese da ima- 
gem de um povo, mais brigão do que pacífico, mais apaixonado que amarrotado. Que fique para a imprensa e para os cartolas a tarefa de tentar atrapalhar o seu trabalho. A culpa será dêles se faltar paz ou mesmo dinheiro para a Seleção conquistar o seu trabalho. (...) Deixe para nós, o povo, apenas o nó na garganta, o frio no coração e o grito infinito da vitória (Placar, 1970, ed.1:5).

Embora ignorando o decreto que impunha limites à imprensa, Placar não foi censurada. Na edição seguinte, trouxe uma "carta aberta" de cinco páginas escritas pelo agora novamente jornalista João Saldanha. O texto chama Pelé de "ingênuo", pede intervenção na $\mathrm{CDB}^{9}$ e apela que "ponha até polícia dentro do vestiário, mas não deixe mais que envenenem os jogadores" (1970, ed.2:26). Placar já nasce, de certo modo, com sua veia politizada. De confronto. Não se exime de potencializar as mazelas do sistema que envolve o futebol e abordar suas controvérsias. Por outro lado, não se pode dizer exatamente que havia total isenção à linha ideológica do governo.

Afinal, dois agentes foram cruciais para impulsão da revista: a proximidade da Copa do Mundo, no México, onde o Brasil se sagraria tricampeão, e a implantação da Loteria Esportiva no país, lançada sob o slogan "Aprenda a ficar tão rico quanto Pelé". De acordo com Coelho (2011), movida pelo bolão, com seção destinada a dicas e aos tradicionais tabelões, a Placar, ao custo de 1 cruzeiro, chegou a vender 250 mil exemplares em 1972. Mas não era só isso.

Ter a publicidade da Loteria, pertencente ao Governo Federal, um de seus principais anunciantes, requeria à Placar um certo jogo de cintura. A postura dicotômica é apontada por Malaia (2012:166) em discursos publicitários e em reportagens que tinham cunho elitistas de análise do futebol brasileiro. "Não se pode perder de vista que Placar se tratava de uma publicação de uma das maiores editoras do Brasil. Por isso, não seria de estranhar que a revista tivesse em seus discursos características da classe que representava”. A aproximação com o projeto da Loteria não deixava a revista alheia a um dos principais projetos da Ditadura em relação ao esporte. A história entre a Placar e a Loteria não se encerraria por aí.

Mas, na convergência do sucesso do periódico, vieram também o Campeonato Brasileiro em 1971 (antes tinha o nome de Torneio Roberto Gomes Pedro$\mathrm{sa}^{10}$ ) e a criação do tradicional troféu Bola de Prata, no primeiro ano da revista, para premiar os melhores do Brasileirão. Com ambição de ser nacional, Placar tinha repórteres nas principais praças esportivas do país, como no Recife, capital do estado de Pernambuco, no Nordeste do Brasil, onde o jornalista Lenivaldo
Aragão, por exemplo, foi correspondente entre 1972 e 1986. Unzelte (2015) destaca ainda a Fórmula 1, que passa a ter mais espaço e trazer receita editorial sobretudo com o sucesso de Émerson Fittipaldi ${ }^{11}$. Apesar da expansão nacional e atestado sucesso de vendas, já sofria com a instabilidade financeira.

Placar teve também as maiores tiragens, em torno de 200 mil exemplares semanais nos seus primeiros anos. Porém, nunca foi uma revista lucrativa, sendo mantida pela Abril certamente para garantir uma fatia do mercado (a do jornalismo esportivo) fora do alcance de seus concorrentes. Durante a maior parte de sua existência, a revista foi sustentada pela célebre filosofia de Victor Civita "O Pato paga”, com seus custos absorvidos pela Editora Abril (Mira, 2001:160).

O "Pato paga" era uma menção ao lucro dado pela revista em quadrinhos do Pato Donald, lançado em 1950 pela Abrilno Brasil e sucesso de vendas e lucro. Suficiente para manter os anos negativos de Veja e Placar. O fato é que, historicamente, a revista esportiva do grupo sempre precisou conviver com as faces de um reconhecido sucesso jornalístico, mas os reveses dos déficits financeiros. Não em vão, precisou passar por várias mudanças editoriais para se sustentar no mercado. Sempre em busca de um lucro que quase nunca veio.

\section{0: UMA REVISTA, MUITAS FACES}

Com ou sem superávit, Placar viveu dias de glórias que tiveram auge na década de 1980 . Seria um período de muitas transformações, com três fases distintas. $\mathrm{O}$ início foi promissor. $\mathrm{O}$ mais emblemático caso veio com a descoberta de uma "falcatrua de um grupo de jogadores, técnicos e dirigentes que arranjava resultados para os testes da Loteria Esportiva" (Coelho, 2011:99). A capa da edição 648, de 22 de outubro de 1982, tinha como manchete: "Desvendamos a máfia da Loteria Esportiva". Foram 12 páginas de nitroglicerina pura sobre um escândalo gigantesco. O petardo jornalístico foi um sucesso. A reportagem, assinada por Sérgio Martins, acabaria com a credibilidade da ação da Caixa Econômica Federal e sua Loteria, ironicamente a principal parceira da revista em sua trajetória inicial.

Três anos depois (da reportagem), a Polícia Federal anunciou a conclusão do inquérito que envolvia 125 pessoas denunciadas pela revista, das quais apenas vinte seriam indiciadas. A falta de provas, apesar das evidências apresentadas nas matérias, fez muita gente desconfiar das intenções de Juca (Kfouri) e da revista que comandava: '(...) De fato, foi a maior vendagem da revista, 300 e tantos mil exemplares. Ao mesmo tempo, eu tinha plena consciência de que nós 
estávamos jogando contra nós mesmos, jogando de bandido, porque estávamos jogando contra os fãs do futebol' (Ribeiro, 2007: 265).

Figura 2 - Placar desvenda a máfia da Loteria no Brasil em 1982

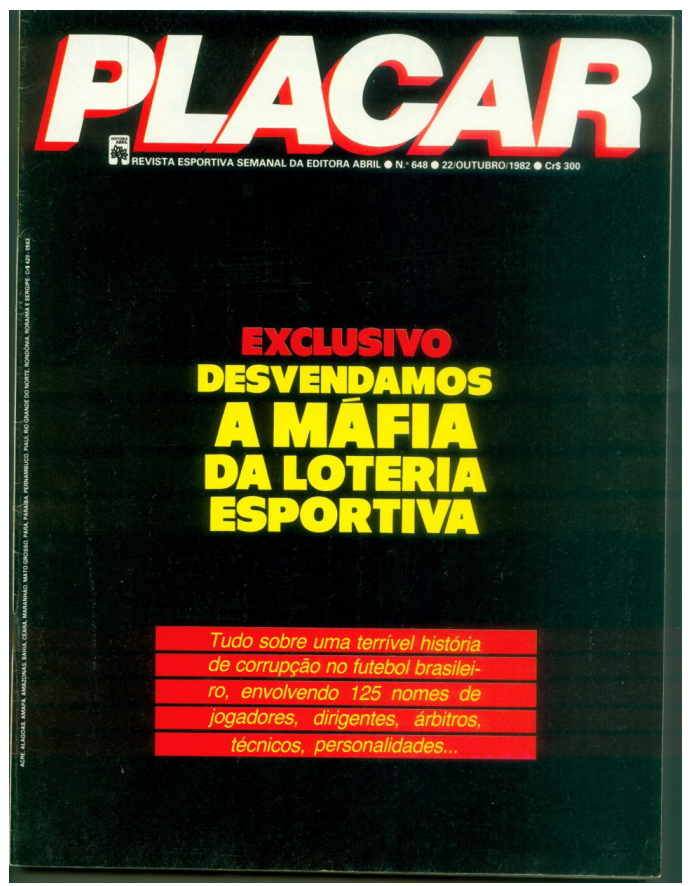

Fonte: Revista Placar/Reprodução

A esta altura, a revista já era mais robusta (com 84 páginas) e tinha a alma militante, que muito se devia ao jovem sociólogo Juca Kfouri ${ }^{12}$, alçado à chefe de reportagem em 1974 e, cinco anos depois, à direção. Personagem ímpar na história da Placar, sentiu na pele ao longo de sua trajetória os desafios de trabalhar com o jornalismo esportivo brasileiro. Um desses episódios aconteceu após a Placar denunciar um caso de doping do meia palmeirense Mário Sérgio, em 1984.

Comentarista do SBT na época, o jornalista foi fazer a cobertura do jogo Guarani x Palmeiras, no estádio Brinco de Ouro, em Campinas (SP). O Guarani venceu por 1 a o e tirou as chances do Palmeiras de ser campeão. "A torcida gritava ' $\hat{\mathrm{E}}$, ê, ê, o Juca vai morrer!'. Na volta, em um posto na estrada, demos de cara com a torcida Mancha Verde. Eu temi pela minha vida" (KFOURI, 2019: informação verbal). Vale ressaltar, que Juca nunca negou o fato de ser torcedor do Corinthians, rival palmeirense.

No início da década de 1980, Juca Kfouri (2019: informação verbal) comandava uma redação de "uns 60 jornalistas. Tinha um correspondente em cada estado. Em regra também um fotógrafo, mas não eram necessariamente contratados. Contratados tínhamos as su- cursais de Brasília, Belo Horizonte, Recife, Salvador, Rio de Janeiro, que era grande, e Curitiba. Eram seis sucursais".

Diante das transformações políticas, no fim do período da Ditadura Militar no Brasil, Placar voltou a mostrar que futebol e política tinham espaço para andar de mãos dadas, sim. No cenário em que "o futebol revelou formas de manifestação por democracia nos estádios com faixas que clamavam por anistia, no discurso de alguns atletas sobre as eleições" (Schatz, 2015:178), em 1982, as eleições foram apresentadas pela revista como uma paixão tão motivadora como o próprio futebol. As edições 726 e 727 , de 22 e 27 de abril de 1984 , trouxeram como capas, respectivamente, dois ícones do futebol nacional com engajamento político.

Na primeira, Pelé vestia uma camisa da Seleção pintada com a frase: "Diretas Já", pedindo eleições diretas para presidente no Brasil. Na segunda, o craque corintiano Sócrates, um dos atletas mais politizados da história do país, com a manchete: "Se o Brasil mudar, eu fico”. Na época, o Sócrates garantiu que se a emenda Dante de Oliveira ${ }^{13}$ fosse aprovada, ficaria no país. Acabou não cumprindo a promessa: foi para a Fiorentina, da Itália. Com a postura, a revista marcava a mistura de política e futebol (Schatz, 2015) e provava que os atletas do esporte mais popular do país estavam cientes das demandas populares e das medidas políticas e sociais mais urgentes. À frente da revista, Juca Kfouri queria a moralização do país e do futebol. E foi à luta.

Crítico da desorganização do futebol brasileiro, a partir de 1986, o jornalista passou a exercer o cargo de vice-presidente do Conselho Regional dos Desportos, órgão ligado a Conselho Nacional dos Desportos (CND). Ribeiro (2007:264) afirma que o alvo de Juca não era apenas os que tentavam se beneficiar dos esquemas armados por dirigentes, "o alvo seria seus próprios companheiros de profissão”. O repórter Oswaldo dos Santos, da Gazeta Esportiva, por exemplo, foi acusado de ganhar 1,5 milhão de dólares como prêmio pela cobertura da Seleção Paulista no Japão, em 1986. Juca ganharia amigos, mas também muitos inimigos.

Em paralelo a tudo isso, a Placar convivia com a instabilidade financeira. Apesar de ter uma equipe de jornalistas reativos, das mais qualificadas do país, e de toda a repercussão com as pautas investigativas e reportagens que traziam à luz o submundo do futebol brasileiro, os fracos resultados econômicos da revista levaram a revista "por várias vezes às portas do encerramento de suas atividades" (Coelho, 2011:98). Em 1984, no vermelho, o filho do fundador e diretor editorial do Grupo Abril, Roberto Civita, estava decidido a mudar a revista, o que aconteceria mesmo a contragosto da equipe, inclusive de Juca Kfouri, para quem 
a mudança se tratou de um erro, admitiria o jornalista três décadas depois (Unzelte, 2015).

Civita, com o poder em mãos, criou a Placar Todos os Esportes, inspirada na Sports Illustrated, sucesso nos Estados Unidos. Vieram nas páginas da Placar esportes como boxe, vôlei, basquete, automobilismo, atletismo e futebol de mulheres, que a essa altura já havia aparecido em outras edições do periódico. Mas, pela primeira vez na história da revista, na edição 738, em julho de 1984, as mulheres "ganham" uma capa sobre o assunto. A manchete, "3.00o times e 45.000 mulheres em campo", tem a jogadora Vandira, do já extinto Pinheiros-PR, de costas, trajando a camisa do clube e uma calcinha branca, no vestiário. $\mathrm{O}$ exemplo traz um perfil normativo estigmatizado de gênero da época, preocupado em primeiro plano com a sensualização da mulher (Leal, 2020).

Figura 3 - A primeira capa dedicada ao futebol de mulheres e a luta pela democratização do país vieram na versão Placar Todos os Esportes

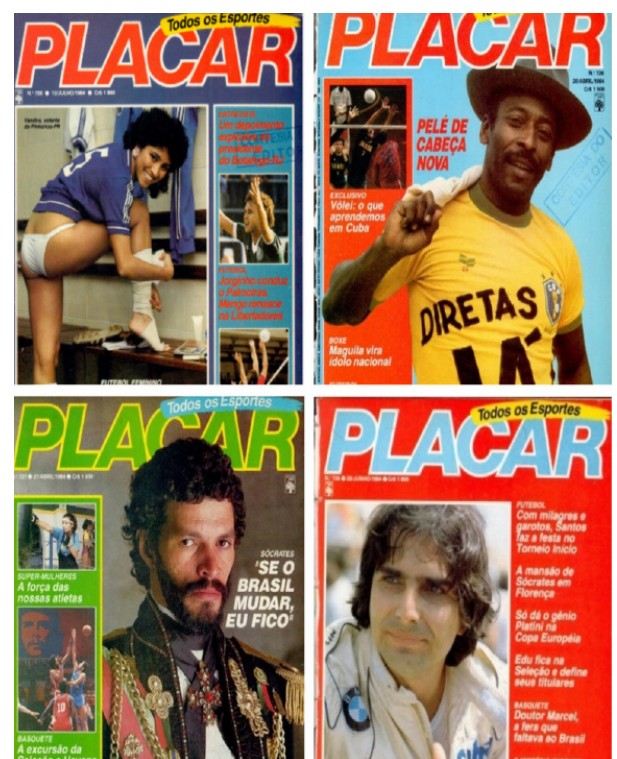

Fonte: Revista Placar/Reprodução

Apesar das tentativas de trazer uma gama maior de assuntos, a Placar Todos os Esportes não engrenou. A Sports Illustrated brasileira não conseguiu atender os anseios de um público aficionado por futebol, eterno carro-chefe da revista. Com a queda brusca de vendas, a versão duraria exatas 30 edições, entre o número 726 , de 20 de abril, e o 755 , de 9 de novembro de 1984. Juca Kfouri (2019: informação verbal) justificou assim:

Eu adoraria fazer a revista poliesportiva, te dá muito mais oportunidade de fazer bom jornalismo. Mas quando a gente fez Placar Todos os Esportes nós perdemos boa parte dos leitores de Placar que achavam que nós estávamos roubando espaço do futebol e não conquistamos o cara que gosta de basquete, de voleibol, de atletismo, que achava que a gente não era a autoridade para falar. A gente contratou gente da melhor qualidade para fazer a revista. E contratamos consultores aqui no Clube Pinheiros. Um cara que tinha acabado de chegar da Romênia, era um gênio, "Slav" num sei das quantas. Ele treinava o Pinheiros e era o nosso consultor para a gente não falar bobagem. Mas Placar era futebol, diziam. E aí é a tal história: ou você está num sistema econômico diferente, onde você pode insistir porque uma hora as pessoas vão consumir ou você perde para as regras do mercado, da oferta e da procura. A questão mercadológica é absolutamente decisiva.

Com o fim da versão "Todos os Esportes”, a revista volta toda sua atenção novamente ao futebol. Desta vez, com um formato renovado, tanto no conteúdo quanto fisicamente. Com o jornalista Carlos Maranhão recrutado junto à Veja, Placar passa a circular de maneira semelhante à coirmã, com a forma 27 por 21 centímetros, menor que a anterior. Unzelte (2015:156) classifica o período do semanário esportivo como a "Veja do futebol" e explica: "Muitas seções publicadas em Placar, como 'De Primeira', 'A Semana', 'Entrevista' e 'Onde Anda', eram semelhantes às que eram publicadas em Veja, como 'Gente', 'Datas', 'Páginas Amarelas'”.

Um episódio em particular marca esse período. Em 1987, em mais um capítulo do caos no futebol brasileiro, a CBF não organizou o Campeonato Brasileiro. Na ocasião, os treze dos principais clubes do país se juntaram para tentar administrar a competição autonomamente. Fundou-se assim o Clube dos Treze. Juca Kfouri, então diretor da Placar, participou ativamente, indo a todas as reuniões. A revista, crítica à $\mathrm{CBF}$, abraçou a fundada Copa União, que terminaria com uma questão jurídica envolvendo Flamengo e Sport, tendo a equipe pernambucana se sagrado campeão brasileiro "de direito"14 (Gallindo; Zirpoli, 2018). Juca Kfouri e a Placarjamais reconheceram o Sport campeão. A revista, inclusive, chegou a confeccionar e oferecer a taça ao Flamengo.

Ribeiro (2007:265) afirma que no início de 1988, a Placar voltou a ter uma queda de vendas. "Para quem vencia em média 120 mil exemplares, 40 mil era quase nada”. Em setembro daquele ano, a edição 952 da revista trouxe mais uma repaginação, transformando-se em Placar Mais por 30 semanas, até abril do ano seguinte. Maior $(30 \mathrm{~cm} \mathrm{x} \mathrm{23,5} \mathrm{cm),} \mathrm{mais} \mathrm{colorida,} \mathrm{de}$ acordo com Unzelte (2015:159) "com todas as páginas (...) impressas em cores” e 100 cruzados mais barata que a anterior (que antes custava 450 cruzados). Mais uma ideia de Juca Kfouri para baratear custos e tentar salvar a revista da falência.

Com perfil "sensacionalista, sem capa, cuspido na banca (...). Essa Placar fez um bom dinheiro”, recorda 
Kfouri (2019: informação verbal). "É uma fase que eu morria de rir, a revista eu achava um horror, mas fazia dinheiro. A revista foi considerada durante um curto período a salvadora da pátria da Abril", acrescenta. O jornalista recorda dos tempos de grande inflação na época. "O dinheiro da assinatura da Veja estava congelado”. A Placar resistiria à crise financeira apenas até $1.051^{a}$ edição, em agosto de 1990, quando chegou ao fim 20 anos de publicações semanais ininterruptas.

A Abril tentou uma substituição por uma revista chamada São Paulo em Ação, que não tardou a mudar para A Semana em Ação. Durou 31 edições. Atento e convicto à Placar, Juca Kfouri nunca desistiu da revista. Mesmo antes do fim da Ação, conseguiu costurar um retorno a baixíssimo custo, com equipe reduzida e sem periodicidade definida, com edições temáticas. O periódico voltaria com o Guia do Brasileirão, ainda no segundo semestre de 1990. Em outubro, veio o especial sobre os 50 anos de Pelé. A revista renasceu como mensal - sem, na verdade, nunca ter morrido para valer.

Como tinha esse núcleo da revista Ação, eu convenci a Editora Abril que a gente não podia perder o nome da revista e, vez por outra, tinha que sair uma edição especial. E que o ideal seria sair já em outubro daquele mesmo ano que o Pelé fazia 50. Acharam boa a ideia. A gente faz a edição do Pelé 50 anos, essa edição vende, esgota, vende 100 mil exemplares. Essa Placar vende isso tudo, esgota com uma redação micro, e em seguida essa edição de Placar ganha o Prêmio Esso ${ }^{15}$ de Jornalismo. E aí, eu convenço a direção da Abril a fazer edições especiais de Placar. A direção aceita desde que a revista não tivesse periodicidade. Só que eu planejo 12 edições para 1991. E eles não percebem. Todo mês saía uma Placar. Fecha a Ação, aí eu mantenho o núcleo com PVC, Sérgio (Martins), Celso Unzelte, Ricardo Corrêa, Alexandre Battibugli e o Anjinho na arte, o Walter Mazzuchelli. A gente mantém um pequeno núcleo, que faz a revista sobreviver (Kfouri, 2019:informação verbal).

\section{Placar e SEXo: UMA REVISTA MACHISTA}

Com uma versão mensal, temática, a revista circularia assim até abril de 1995, quando surgiu o novo projeto Placar Futebol, Sexo e Rock \& Roll, espécie de versão masculina da Capricho e sucesso de vendas, atingindo 250 mil cópias mensais. No conteúdo, todavia, afastava-se do jornalismo que lhe deu fama. O período foi apontado como ligado ao entretenimento (Rocco Junior; Belmonte, 2014) e à objetificação das mulheres em várias instâncias (Salvini; Marchi Júnior, 2016; Leal, 2020).
Além disso, essa nova Placar nasce impregnada por essas transformações no futebol mundial e no cenário político e econômico nacional. "Há nela, um forte sentimento de mudança, um desejo indisfarçável de dar ao futebol brasileiro 'uma cara mais moderna'". (Saldanha, 2009:41). No editorial da edição debutante, o diretor Juca Kfouri anunciava que "o nosso compromisso é o de fazer uma revista de futebol e comportamento como nunca se fez, nem no Brasil, nem no mundo" (Placar, 1995, ed.1102: 8). O estágio marca, então, um momento ímpar da Placar e um dos seus ciclos mais sexualizados, como bem sugeria o slogan.

A Abril contratou Roger Black, diagramador norte-americano, anunciando um projeto gráfico revolucionário. E investiu em uma "agressiva campanha publicitária" (Saldanha; Goellner, 2013:283). O projeto gráfico conceitual e revolucionário era elogiado, mas também um produto demasiado caro (Chiarioni; Kroehn, 2010). A revista tinha dimensões muito maiores do que qualquer outro modelo nacional: $27,5 \mathrm{~cm} \times 35,8 \mathrm{~cm}$. Essa etapa, que duraria até fevereiro de 1999, buscava mostrar que estava no caminho certo: "o esporte mais popular do país poderia ter, sim, uma cara mais moderna e divertida. Estamos comemorando nesta edição dois anos de muito sucesso" (Placar, ed. 1126:14).

Figura 3 - A primeira capa dedicada ao futebol de mulheres e a luta pela democratização do país vieram na versão Placar Todos os Esportes

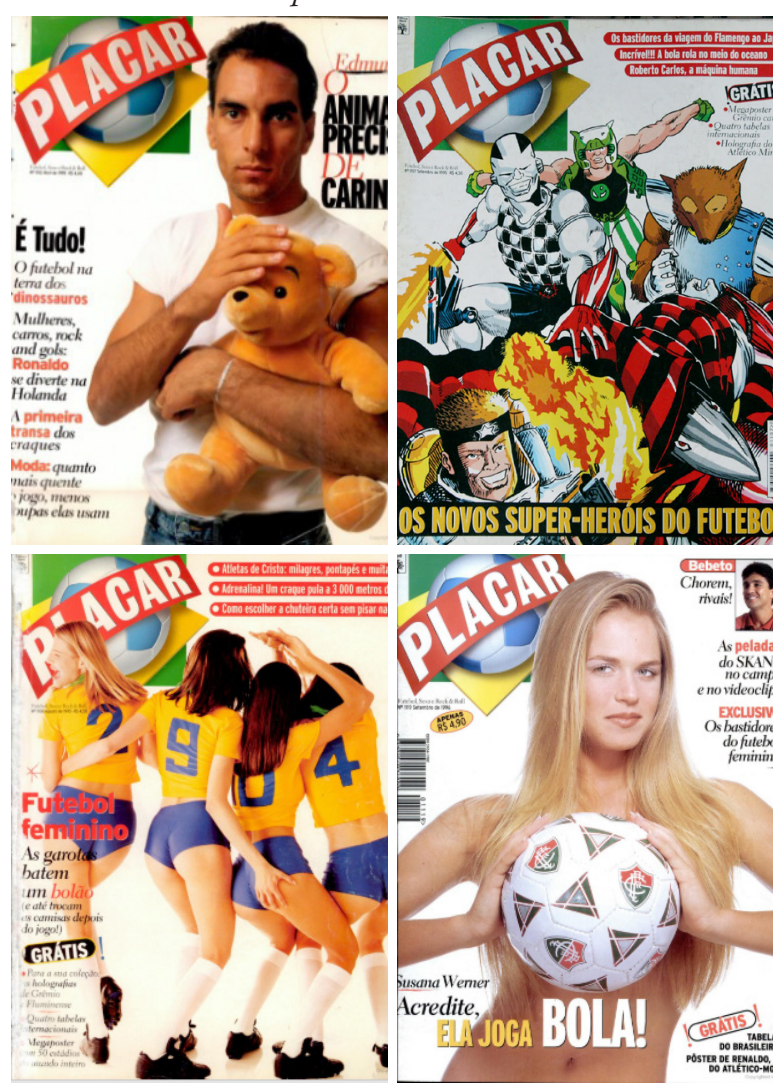

Fonte: Revista Placar/ Reprodução 
Pela primeira vez, a revista passaria a vender assinaturas. "O cenário econômico (inflação sob controle e dólar desvalorizado) e esportivo (como a conquista do tetra e a Lei Zico) levaram a editora a apostar em sua completa reformulação" (Saldanha; Goellner, 2013:282). O foco editorial das publicações era o mesmo de sempre: futebol - porém, reformulado em matérias e reportagens que envolviam o comportamento dos atletas, um forte viés de entretenimento e, claro, uma hipersexualização feminina no esporte.

Percebe-se uma mudança no modo de retratar os personagens do futebol. As imagens das ilustrações com traços limitados ou de atletas em ação, no campo, chutando a bola, comemorando um gol com os companheiros e/ou a torcida, dão lugar a fotografias no estúdio. Fotógrafos como J. R. Duran (famoso por suas premiadas produções na Playboy), ganham espaço no novo contexto, em que a tensão ou alegria extrema no rosto dos esportistas cedem lugares às poses e aos gestos calculados. Saldanha (2009), ressalta que a representação de futebol moderno que se produz na Placar, gira em torno de três eixos principais: 1) a gestão moderna; 2) o torcedor moderno; e 3 ) o jogador moderno.

Na primeira edição da fase Sexo e Rock \& Roll, a já citada edição 1102, o polêmico atacante Edmundo surge na capa posando com um ursinho de pelúcia - o intuito era ir de encontro ao temperamento do jogador brigão, apelidado de "animal". A manchete "O animal precisa de carinho" foi um sucesso de vendas. Autor da matéria (e anos depois de uma biografia do jogador), Sérgio Xavier Filho (2019:informação verbal) recorda-se da produção: "Aquela revista vendeu $240 \mathrm{mil}$ exemplares. Ninguém vendia isso. E criou uma legião de novos leitores. A Placar tem uma marca muito forte, mas era uma marca muito envelhecida até 1995".

O período marcou a demissão, em 1995, de Juca Kfouri por divergências editoriais com a cúpula da empresa. Na verdade, o jornalista teve a demissão solicitada por Ricardo Teixeira, então presidente da CBF e desafeto de Juca. O jornalista Marcelo Duarte assume a direção da revista ciente que tinha em mãos um produto cujo público-alvo era o homem. Historicamente foi e ainda hoje ${ }^{16}$ é assim.

Especificamente na fase Futebol, Sexo \& Rock and Roll, na década de 1990, Duarte (2019:informação verbal) justifica que o foco era voltado para o público masculino porque o "público-alvo era o jovem, o garoto. Era o adolescente... E o jovem adulto. Era justamente para pegar esse público masculino, a versão masculina dos leitores da (revista) Capricho, que tinha um mercado consumidor muito grande”. Repórter da Placar no período, o jornalista Paulo Vinícius Coelho (2019:informação verbal) era uma voz dissonante às diretrizes editoriais da época.

A Abril chegou a vender 500 mil exemplares. E a Capricho tinha uma relação com a menina que a Abril entendia que era como uma irmã mais velha. A menina de 12, 13 anos tinha na Capricho uma referência de relação com o namorado, de maquiagem, de beleza, de cabelo, de coisas de menina. E o Thomaz (Souto, diretor da Abril) falava assim: "Então, a gente quer que Placar seja o irmão mais velho do menino”. E eu pensei: “idiota!". Ele não percebeu que isso já acontece. Porque Placar foi meu irmão mais velho nesse sentido dos meus 10 anos aos 21. (...) Eu achava o projeto uma merda, porque o projeto violentava minha relação umbilical com a revista. Agora, você pega a revista hoje tem muita matéria de altíssima qualidade. A equipe era muito boa. Tinha muita coisa legal, mas tinha um balanço que eu acho equivocado. Não era uma revista de futebol, era uma revista de comportamento.

Paulo Vinícius Coelho (2019:informação verbal) acredita que a Editora Abril errou ao tentar equiparar a Placar à revista Capricho e focar na alteração da sua linha editorial para temas que circundavam o futebol (essencialmente, a vida dos atletas extracampo, em reportagens com ensaios fotográficos, longas entrevistas), mas deixava o esporte em segundo plano. No embalo da fase apontada por Coelho (2019:informação verbal) como "revista de comportamento", a Placar Futebol, Sexo e Rock \& Roll abusava também dos perfis sexualizados não só das futebolísticas, mas de todas as mulheres do meio esportivo.

É neste época, por exemplo, que surgem seções como "Deusa", caracterizadas pelo curto texto ilustrado com fotos enormes, em geral em página dupla, de mulheres seminuas, as "musas"; ou de eleições como "as leitoras mais gostosas" e as com o bumbum mais bonito, que aconteciam por meio da seção "Cartas" nos anos de 1996 e 1997 (Leal, 2020). É neste período onde a construção da mulher atleta pela revista é intensificada como uma figura passível de objetificação, vítima de uma estrutura associada à masculinidade e ao machismo (Barreto Januário, 2019).

A edição 1106, de agosto de 1995 é um exemplo clássico. A manchete estampava: "Futebol Feminino - As garotas batem um bolão (e atétrocam as camisas depois dojogo!)”. $\mathrm{Na}$ fotografia, quatro modelos, de costas, vestindo uniforme amarelo e azul provocativo, que em nada remetia às roupas que a real Seleção Brasileira feminina usava: as sobras reaproveitadas da Seleção masculina - o primeiro design exclusivo para mulheres veio somente na Copa do Mundo 2019 (Leal, 2020).

O título da notícia trazia o aviso: "Homens, chegamos!”. O lead é iniciado desta forma: "Perninhas de 
fora, chuteiras pequenas, top nos seios, as garotas finalmente descobriram a paixão pela bola. Depois da Copa do Mundo, o futebol feminino explodiu" (Placar, 1995, ed. 1106:33). A publicação veio permeada por uma clara dualidade. O cerne da notícia era mostrar como o futebol vinha ganhando notoriedade entre as mulheres, deixando para trás um preconceito sobre a modalidade, com aumento exponencial da prática, estimulado pela Copa de mulheres daquele ano. A matéria traz a proibição histórica da mulher no esporte ${ }^{17}$, apresenta evolução técnica feminina e questiona a falta de investimento, profissionalização e gestão especializada. Informações relevantes, ilustradas com gráficos e fotos.

Por outro lado, o material não deixa de se distanciar à espetacularização dos corpos, da mulher jogadora como algo sexy e até vulgar. A reportagem tem no total oito páginas, sendo três destinadas apenas a fotografias com as modelos posando ou trocando a camisa, deixando os seios à mostra. "O melhor do jogo. Confesse. Você sempre imaginou como seria se, ao final da partida, as garotas imitassem os homens e trocassem as camisas em campo, não? Placar realiza o seu sonho. Afinal, futebol é confraternização" (Placar, 1995, ed. 1106:38-39).

Marcelo Duarte (2019:informação verbal) enxerga o perfil editorial daquela revista como à frente do seu tempo. Ele justifica que aquela Placar buscava dialogar com o adolescente homem, público-alvo, da mesma forma com que a Capricho, revista feminina da editora Abril, dialogava com as meninas. Especificamente sobre a edição 1106, o ex-comandante da revista analisa hoje que:

Essa (matéria) que você está falando, dos shortinhos, não é uma matéria que me agride. Eu fico lembrando de uma outra, da Placar Todos os Esportes (1984), que era falando de futebol feminino. E aí tinha uma jogadora do Pinheiros, uma menina que não tinha relevância nenhuma dentro da matéria, mas era linda e estava de calcinha no vestiário ${ }^{18}$. Acho que aquilo não caberia mais hoje. Pelo que se fala do feminino e tal. Essa outra é uma matéria que está muito mais elegante. Era uma foto com um fotógrafo bacana (J. R. Duran)... Não lembro exatamente da matéria, lembro da foto. Não acho que tenha ali uma coisa tão apelativa. Eram modelos, eu acho. Acho que eram modelos... Se você olhar a Placar Mais (1988), você vai ver o que era a coisa apelativa. E a gente tava de alguma forma querendo falar de sexo com os garotos. Da mesma forma que a Capricho falava de sexo com as meninas, a gente falava de sexo com os meninos. Fazia parte da receita da revista. E a gente não estava falando com homens, estava falando com meninos ainda. Tinha um cuidado para não soar muito apelativo. Sensual, a revista era bastante. A gente tinha a preocupação de passar uma carga de sensualidade, mas dentro de um certo respeito, de um certo limite. Era uma revista elegante (Duarte, 2019:informação verbal).

Na década de 1990, de acordo com Leal (2020), $58,38 \%$ das publicações sobre futebol de mulheres tinham conotação sexual - na década de 2010, o número cai para 10,87\%. A partir de 1997, já sem Juca Kfouri, a Placar Futebol, Sexo e Rock \& Roll começa a perder força novamente. A revista voltaria a lutar pela sobrevivência. Tentou-se de tudo ${ }^{19}$. Até reimprimir a revista semanal, entre abril de 2001 e fevereiro de 2002. Não deu certo. A partir de então, chegaria uma fase que basicamente dura até hoje: a das edições especiais.

Figura 5 - Neymar crucificado foi alvo de críticas na Placar

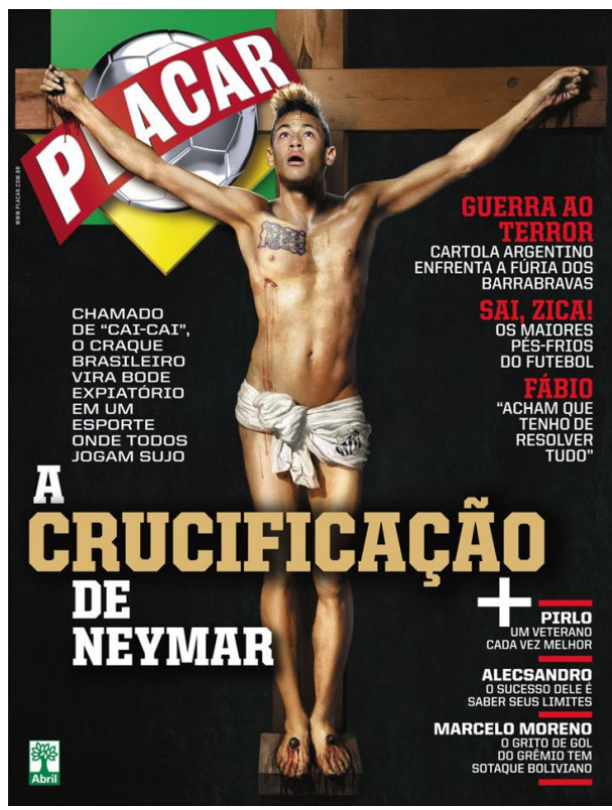

Fonte: Revista Placar/ Reprodução

Em outubro de 2012, tendo o jornalista Maurício Barros como diretor (função que exerceu entre 2011 e 2015), a revista voltou a repercutir nacionalmente trazendo na edição 1371 o atacante Neymar crucificado, o que gerou muita discussão na comunidade cristã e reclamações da Conferência Nacional dos Bispos do Brasil.

A gente tinha os desafios de ser uma revista mensal no momento em que chegava a internet dando uma cobertura em tempo real. E aí veio a reflexão como você consegue permanecer relevante falando de algo real de um universo, que 
é quente, que enfrenta uma cobertura maciça, que é muito visual. O que é legal no futebol? É ver jogo no estádio ou na televisão, ouvir o jogo. E como a gente ainda se mantém relevante enfrentando essas dificuldades? Então, uma revista que cheguei apostava muito em grandes perfis, em curiosidades (Barros, 2019:informação verbal).

\section{UM BREVE ADEUS E O RETORNO REFORMADO}

Em 2014, a Editora Abril vendeu dez revistas para a Editora Caras $^{20}$. A vez da Placar chegaria em junho do ano seguinte, sendo a edição 1403 a "última" na antiga casa. A tradicional publicação esportiva, que na década de 1980 chegou a ter mais de 50 colaboradores na equipe, passou a ter Celso Unzelte, como editor-chefe, e Rodolfo Rodrigues, como editor, além de dois estagiários. Unzelte (2019:informação verbal) aponta o período como sendo de uma "revista esquizofrênica" pelas intervenções de Edigardo Martolio, diretor editorial da Caras, "preocupado apenas em encher as páginas". Por divergências, o jornalista pediu demissão em três meses.

Edgardo não sabia direito o que ele queria. Ele queria encher de página... Você deve ter visto, aquela revista ela é bem esquizofrênica. Justamente por isso também, porque ele é bem centralizador. Se trancava lá naquela sala. Paria páginas e páginas, porque queria aumentar a estrutura, e queria colocar outros esportes, futebol feminino, olimpíada dos índios. Não por filosofia, mas tentando também captar patrocínio, cair nas graças do Ministério dos Esportes (Unzelte, 2019:informação verbal).

Em outubro de 2016, a editora Abril, ainda hoje em processo de recuperação judicial, chega a um acordo e reassume o comando da revista. Sem equipe de esportes, a empresa contratou o jornalista Ricardo Corrêa, por muitos anos, editor de fotografia da Placar, para assumir as diretrizes do periódico. Com uma equipe de mais dois editores, um de texto e outro de fotografia, além de colaboradores pontuais, o mais tradicional periódico esportivo do país voltou a funcionar, sem redação própria, de maneira terceirizada, com "edições especiais, colecionáveis ou úteis, como os guias que produzimos", explicou Corrêa (2019:informação verbal).

Foi neste período também que a Placar fez um revisionismo histórico relativo ao futebol de mulheres. A edição 1453, de julho de 2019, trouxe o título "A busca pela igualdade”, que era um pedido de desculpas histórico pela trajetória machista da revista ao noticiar, não só o futebol de mulheres, mas as mulheres no esporte como um todo. O pedido de desculpas foi aprovado também por ex-editores, como Juca Kfouri, Sérgio Xavier Filho, Maurício Barros, entre outros (Leal, 2020).

A edição 1457, de novembro do mesmo ano, trouxe pela primeira vez, sozinha na capa, a atacante Marta, eleita seis vezes a melhor jogadora do mundo - um recorde. Sob a manchete "Dossiê futebol feminino", a revista anunciava: "a edição especial traz raio- $X$ da modalidade no Brasil e no mundo". Corrêa (2019:informação verbal), autor do editorial que pediu desculpas às mulheres, afirmou que "pela histórica tradição democrática, a Placar merecia isso”.

Com Ricardo Corrêa, a revista passou a funcionar com um planejamento de pautas anuais, prevendo os grandes eventos agendados para os meses determinados. Ao traçar o novo perfil editorial nesta fase, o jornalista afirmou que a busca da revista passou a ser transformar-se em um documento histórico, atemporal, com estatísticas, histórias e um rico material para fazer vibrar qualquer pesquisador da posteridade. Um dos grandes trunfos da Placar para ter edições mais trabalhadas é o seu arquivo histórico. De acordo com Corrêa (2019:informação verbal), o acervo da Placar tem cerca de 6 milhões de imagens, desde a década de 1970, coloridas, com jogos de ídolos como Cruyff, Pelé, Romário, dentre outros.

Figura 6 - Pela primeira vez, Placar tem edição exclusiva dedicada ao futebol de mulheres

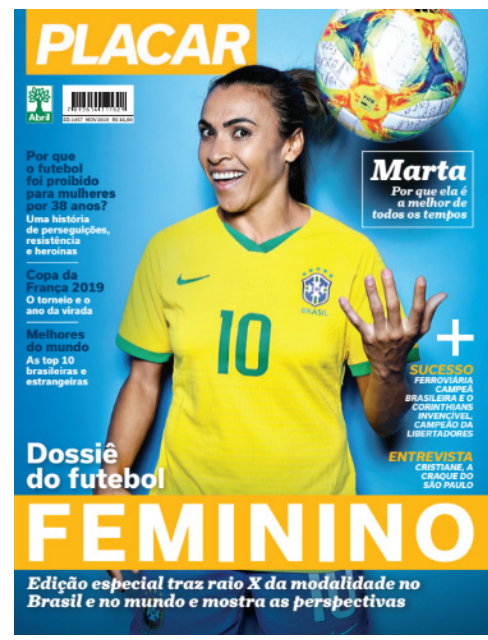

Fonte: Revista Placar/Reprodução

Corrêa ficou no projeto até o final de 2019. Em 2020, no cinquentenário da revista, o editor passou a ser o jornalista Fabio Altman. De acordo com dados da Editora Abril de junho de 2020, Placar possui 2.537.000 leitores ativos em todas as plataformas, o que engloba a revista física, nosso objeto de pesquisa, mas também a sua versão digital, que apenas reproduz a versão impressa. Em um dado mais próximo à realidade atual do periódico, Placar trabalha com uma tiragem mensal de 11.179 exemplares (Editora Abril, 2020), entre vendas 
avulsas (3.200) e assinaturas (7.979), bem distante de décadas anteriores, quando facilmente se passava da casa dos 100 mil exemplares (Coelho, 2011). Apesar disso, a história da Placar é, no Brasil, apontada como "a experiência mais bem-sucedida nessa área (esportiva), embora cheia de altos e baixos" (Scalzo, 2006:36).

\section{CONSIDERAÇõES FINAIS}

Entendemos a revista Placar como uma referência singular para o jornalismo esportivo no Brasil. Como parte da mídia, também foi ao longo dos anos, de certo modo, um catalisador dos anseios e câmbios sociais e, por isso, esteve sempre em processo de mutação. Nesse sentido, compreendemos atividade "jornalismo esportivo", a partir da trajetória trazida nos 50 anos da revista Placar e sua matéria-prima, a notícia, como um instrumento que colaborou no desenvolvimento do esporte nacional através de manifestações políticas, espaço a vozes democráticas e pelas inúmeras discussões que cercaram a profissionalização do futebol brasileiro.

Enxergamos as metamorfoses da Placar nas suas noticiabilidades, perfis e fases atravessadas pela revista ao longo das cinco décadas como uma relevante conexão para a troca de sentidos entre jornalismo e sociedade. O periódico consolidou-se no país na medida em que renovou-se em seus editoriais, seções, formatos, interação com a audiência, até a mais recente inserção ao meio digital, tornando-se, de alguma forma, apesar da instabilidade financeira que sempre a cercou, conectada aos torcedores, muitos dos quais tiveram com a Placar uma espécie de "irmão mais velho" no passado e não em vão mantêm um laço sentimental com a marca.

Nesse sentido, o periódico acompanhou as transformações sociais, descrevendo-a e, paralelamente, sendo influenciada pelo contexto social. Não é apenas um evento que faz uma noticiabilidade ganhar novas formas, mas toda uma cadeia de fatos e ações.

Ao analisar, por exemplo, o futebol de mulheres, observamos que tratamentos sexistas como os de "musas" e "gostosas" foram ficando para trás em consequência de mudanças sociais pautadas pela luta e das mulheres através de movimentos feministas. $\mathrm{O}$ mesmo pôde-se observar quando a revista deu voz a jogadores que não se furtavam a declarar seu posicionamento político (no contexto de efervescência em torno da redemocratização do país) ou de discussões em torno da profissionalização do futebol nacional ou denúncias sobre corrupção no nosso esporte.

Propusemos estudar o enfoque do jornalismo esportivo praticado por meio da Placar porque enten- demos que a revista, por sua tradição e longevidade, tem um valor ímpar no jornalismo esportivo brasileiro e consegue refletir em suas páginas as dramatizações sociais de cada época, sem perder a particularidade de se autorreinventar como produto jornalístico.

$\mathrm{Na}$ busca por sobrevivência, muitas estratégias e ideias ganharam vida. Surgiram, conforme apresentamos, dentre outras fases, a Placar Mais (1984), Placar Todos os Esportes (1988), a versão Futebol, Sexo \& Rock and Roll (1995 a 1999). Esses momentos, significam, respectivamente: um perfil sensacionalista e popular; um momento de busca pela descentralidade do futebol como eixo único; e um período ligado ao entretenimento e notícias de comportamento. Cada qual com suas especificidades e enquadramentos jornalísticos.

Entender a relação do esporte e da mídia esportiva no Brasil é compreender uma dimensão importante da formação do país como nação. Existe uma linha tênue entre a história da sociedade brasileira e a história do futebol no país. Por isso, acreditamos que resgatar a trajetória da Placar no país e apresentar como a mais tradicional revista do segmento se mantém viva é também trazer um capítulo relevante do entrelaçamento da cultura esportiva com a cultura social no Brasil.

Por fim, defendemos que é impossível precisar qual o impacto exato da contribuição da Placar para o jornalismo esportivo e sua influência acerca do futebol brasileiro. Entretanto, ainda que não haja essa régua para os dois quadros, parece-nos significativo que, ao observar a trajetória cinquentenária deste veículo, suas matérias de cunho social, o envolvimento com movimentos políticos e, mais recentemente, com a mudança de postura relativa ao futebol de mulheres, pode-se afirmar que a revista foi, sim, uma peça relevante na promoção e desenvolvimento de tendências sociais, a partir das inseridas no campo do jornalismo esportivo.

Submetido em 1 de outubro de 2020 Acetio em 12 de junho 2021 


\section{Notes}

1. O tabelão é um conhecido espaço de serviço esportivo, voltado aos resultados de partidas ou competições ou simplesmente às datas, aos horários e aos locais de diferentes disputas e modalidades.

2. Com slogan "Placar tira as dúvidas mais cabeludas", a seção abriu espaço para perguntas dos leitores sobre temas históricos, curiosos e polêmicos. Era mais um meio de interatividade proporcionado na década de 1990 .

3. Seção sobre personagens históricos do esporte já falecidos, mas presentes pelo legado.

A seção, lançada na passagem da revista pela Editora Caras, com slogan "O mais importante de cada dia no futebol" trazia notas curtas sobre os acontecimentos do mês, com informações separadas por data, dia a dia.

Seção com informações estatísticas, curiosidades, recordes e números ligados ao esporte.

6. Até a década de 1970, a Gazeta Esportiva e o Jornal dos Sports foram periódicos que reinaram quase absolutos no país. C.f. $O$ esporte na imprensa e a imprensa esportiva no Brasil (Buarque de Hollanda; Melo, 2012).

7. Lançada em 1952 pelo fundador da Editora Abril, Victor Civita, foi a primeira revista feminina do Brasil.

8. Saldanha teria plantado a informação que Pelé estaria míope e, por isso, sem condições de atuar. A história é contada com primor pelo documentário Pelé, lançado pela Netflix, em 23 de fevereiro de 2021.

9. Confederação Brasileira de Desportos, extinta em 1979. Atualmente, é Confederação Brasileira de Futebol (CBF).

10. Trata-se da competição equivalente ao Campeonato Brasileiro, disputada entre 1967 e 1970.
11. Brasileiro bicampeão mundial de F1, em 1972 e 1974.

12. Começou na revista em 1970, como pesquisador do Departamento de Documentação, e ficou até 1995.

13. A emenda tinha por objetivo reinstaurar as eleições diretas para presidente da República no Brasil.

14. Para entender melhor o imbróglio, ler a obra jornalística 1987 - De fato, de direito e de cabeça (Gallindo; Zirpoli, 2018).

15. Premiação mais importante do jornalismo brasileiro. A revista viria a repetir a façanha na edição de junho de 1992 com a seguinte manchete: "A eterna lenda chamada Garrincha".

16. De acordo com dados da Editora Abril em 2020, $90 \%$ da audiência da revista era composta pelo público masculino, enquanto os outros $10 \%$, o feminino.

17. Devido ao Decreto-Lei1 no 3.199 de abril de 1941, na ditadura do governo Getúlio Vargas, as futebolistas ficaram oficialmente 38 anos impedidas de entrar em campo no Brasil, relegadas à clandestinidade até 1979 .

18. O jornalista se refere à já citada edição 738 , da versão Placar Todos os Esportes, de julho de 1984, que traz a jogadora Vandira, do Pinheiros-PR, de calcinha na capa.

19. Unzelte (2015) recorda que, em novembro de 2008, a Placar lançou um jornal, em formato tabloide, de distribuição gratuita. Durou apenas 22 edições.

20. Em 2014, foram vendidas Aventuras na História, Bons Fluidos, Manequim, Máxima, Minha Casa, Minha Novela, Recreio, Sou+Eu, Vida Simples e Viva Mais; seguindo de, em 2015: AnaMaria, Arquitetura \& Construção, Contigo!, Tititi, Você RH, Você S/A e Placar. 


\section{REFERÊNCIAS BIBLIOGRÁFICAS}

Barreto Januário, S. (2019) Mulheres no campo: o ethos da torcedora pernambucana. São Paulo: Fontenele.

Barros, M. (2019). Entrevista concedida pelo jornalista, exeditor da revista Placar, ao autor deste artigo. São Paulo.

Broustau, N.; Jeanne-Perrier, V.; Le Cam, F., Pereira, F. H. (2012). A entrevista de pesquisa com jornalistas, Sur le journalisme, About journalism, Sobre jornalismo, $\mathrm{Vol} 1, \mathrm{n}^{\circ} 1$.

Buarque de Hollanda, B. B.; Melo, V. A. (Orgs.) (2012). O esporte na imprensa e a imprensa esportiva no Brasil. Rio de Janeiro: 7 Lestras.

Chiarioni, B.; Kroehn, M. (2010). Onde o esporte se reinventa: histórias e bastidores dos 40 anos de Placar. São Paulo: Primavera Editorial.

Coelho, P. V. (2011). Jornalismo esportivo. São Paulo: Contexto.

(2019). Entrevista concedida pelo jornalista, exrepórter da revista Placar, ao autor deste artigo. São Paulo.

Corrêa, R. (2019). Entrevista concedida pelo jornalista, exeditor da revista Placar, ao autor deste artigo. São Paulo.

Duarte, J. Entrevista em Profundidade. (2010). In: Duarte, J; Barros, A. Métodos e Técnicas de Pesquisa em Comunicação. 2.ed. São Paulo: Atlas.

Duarte, M. (2019). Entrevista concedida pelo jornalista, exeditor da revista Placar, ao autor deste artigo. São Paulo.

Editora Abril. (2020). PubliAbril (Audiência/Circulação). São Paulo: ed. Abril, 2020. Disponível em: http://publiabril. abril.com.br/marcas/placar/plataformas/revista-impressa. Acesso em: 2 de jun. de 2020.

Gallindo, A; Zirpoli, C. (2018). 1987 - De fato, de direito e de cabeça. São Paulo: Onze Cultural/Zinnerama.

Gonçalo Júnior. (2005). O Homem Abril: Cláudio de Souza e a história da maior editora brasileira de revistas. São Paulo: Opera Graphica Editora.

Hime, G. (2005). Construindo a Profissão de Jornalista: Cásper Líbero e a Criação da Primeira Escola de Jornalismo do Brasil. In: Congresso Brasileiro de Comunicação, 28. 2005. Rio de Janeiro. Anais. São Paulo: Intercom.

Kfouri, J. (2019). Entrevista concedida pelo jornalista, ex-diretor de redação da revista Placar, ao autor deste artigo. São Paulo.

Leal, D. (2020). Noticiabilidade na Placar: a mutação dos valores-notícia em três décadas de cobertura do futebol de mulheres (Dissertação de Mestrado). Programa de Pós-Graduação em Comunicação, Universidade Federal de Pernambuco, Recife, PE, Brasil.

Malaia, J. (2012). Placar: 1970. In: Buarque de Hollanda, B. B.; Melo, V. A. (Orgs.). O esporte na imprensa e a imprensa esportiva no Brasil. Rio de Janeiro: 7 Lestras.

Mira, M. C. (2001). O leitor e a banca de revistas: a segmentação da cultura no século XX. São Paulo: Olho d'Água/ Fapesp.

Placar. (1970). São Paulo: ed. Abril, edição 1.

(1984). São Paulo: ed. Abril, edição 726.

(1984). São Paulo: ed. Abril, edição 727.

(1995). São Paulo: ed. Abril, edição 1102.
(1995). São Paulo: ed. Abril, edição 1106.

(1997). São Paulo: ed. Abril, edição 1126.

(2020). São Paulo: ed. Abril, edição 1453.

(2020). São Paulo: ed. Abril, edição 1457.

Ribeiro, A. (2007). Os donos do espetáculo: histórias da imprensa esportiva do Brasil. São Paulo: Terceiro Nome.

Rocco Junior, A. J.; Belmonte, W. B. (2014). Da informação ao entretenimento: análise do jornalismo esportivo brasileiro pela trajetória histórica da revista Placar. In: Congresso de Ciências da Comunicação na Região Sudeste, 19, Vitória-ES, 2014. Anais do XIX Congresso de Ciências da Comunicação na região Sudeste. Vitória-ES: Intercom.

Saldanha, R. M. (2009). Placar e a produção de uma representação de futebol moderno. 2009. Dissertação (Mestrado em Ciências do Movimento Humano), Universidade Federal do Rio Grande do Sul, Porto Alegre.

Salvini, L.; Marchi Júnior, W. (2016). Registros do futebol feminino na Revista Placar: 30 anos de história. Motrivivência (Florianópolis); v.28, n. 49, p99-113.

Scalzo, M. (2006). Jornalismo de revista. 3. ed. - São Paulo: Contexto.

Schatz, P. (2015). A imprensa escrita entra em campo: relações entre política e futebol através da análise da revista Placar (1974-1982). Dissertação (mestrado), UFSC, Florianópolis.

Silva, L.M.G.da; Brasil, V.V.; Guimarães, H.C.Q.C.P.; Savonitti, B.H.R.A.; Silva, M.J.P.da. (2000). Comunicação nãoverbal: reflexões acerca da linguagem corporal. Rev.latinoam.enfermagem, Ribeirão Preto, v. 8, n. 4, p. 52-58.

Temer, A. C. R. P.; Tuzzo, S. (2017) A entrevista como método de pesquisa qualitativa: uma leitura crítica das memórias dos jornalistas. In: Congresso Ibero-Americano em investigação cualitativa, 6., Salamanca, Espanha, 2017. Anais... Salamanca, Espanha: Universidad de Salamanca, 2017.

Thomas, J. R.; Nelson, J. K. (1996). Research methods in physical activity. 3.ed. Champaign: Human Kinetics.

Unzelte, C. (2019). Entrevista concedida pelo jornalista, exeditor da revista Placar, ao autor deste artigo. São Paulo.

(2015). Futebol em revista no Brasil: dos primeiros títulos à resistente Placar. São Paulo: Dissertação (mestrado) - Faculdade Cásper Líbero, Programa de Mestrado em Comunicação.

Xavier Filho, S. (2019). Entrevista concedida pelo jornalista, ex-editor da revista Placar, ao autor deste artigo. São Paulo. 


\section{RESUMO | RÉSUMÉ | ABSTRACT}

\section{A singularidade da cinquentenária Placar para o contexto histórico do jornalismo esportivo no Brasil}

Le magazine Placar et le journalisme sportif brésilien : cinquante ans d'une histoire singulière

Placar magazine and the history of sports journalism in Brazil : 50 years of singularity

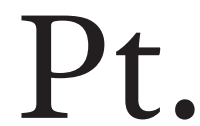

Este trabalho busca trazer uma reflexão acerca da importância da Placar para a construção do jornalismo esportivo no Brasil, fazendo uma sistematização das diferentes fases e seus distintos momentos. Mais longeva revista esportiva brasileira em circulação, o periódico completou, apesar da quase intermitente luta pela sobrevivência, meio século de vida em 2020. Como parte da mídia, também foi ao longo dos anos, de certo modo, um catalisador dos anseios e câmbios sociais e, por isso, esteve sempre em processo de mutação, descrevendo-os e, paralelamente, sendo influenciada pelos contextos das diferentes épocas. Tratamentos sexistas ao futebol de mulheres, como os de "musas" e "gostosas", por exemplo, atravessaram fases históricas da revista, como as versões Placar Mais (1984), Placar Todos os Esportes (1988) e Futebol, Sexo \& Rock and Roll (1995 1999). Com o advento do feminismo, esses termos não apenas ficaram para trás como a revista chegou a publicar em 2019 um pedido de desculpas pelo passado misógino e machista. $\mathrm{O}$ entrelaçamento histórico também pôde-se observar quando a revista deu voz a jogadores que não se furtavam a declarar seu posicionamento político (no contexto de efervescência em torno da redemocratização do país, nas chamadas "Diretas Já") ou de discussões em torno da profissionalização do futebol nacional ou denúncias sobre corrupção no esporte. Neste estudo, evidencia-se a existência de uma linha tênue entre a história da sociedade brasileira e a história do futebol no país. Assim, a partir de entrevistas com sete jornalistas que fizeram parte de diferentes fases da revista (Celso Unzelte, Marcelo Duarte, Maurício Barros, Paulo Vinícius Coelho, Ricardo Corrêa, Sérgio Xavier Filho e o mais longínquo editor, Juca Kfouri), este artigo busca contribuir para a construção histórica de um capítulo relevante do entrelaçamento da cultura esportiva com a cultura social no Brasil através da Placar, uma peça fundamental da história do jornalismo esportivo nacional que se mantém viva.

Palavras-chave: Jornalismo esportivo; Revista Placar; Jornalismo; História do jornalismo esportivo.

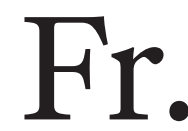

Cet article propose une réflexion surl'importance du magazine Placar dans la construction du journalisme sportif au Brésil, à partir d'une systématisation de ses différentes - phases et des grands moments de son histoire. Premier magazine sportif brésilien, Placar a fêté son jubilé en 2020 , après cinquante années marquées par un combat continuel pour assurer son existence. En tant qu'acteur du monde médiatique brésilien durant toutes ces années, il représente un catalyseur des aspirations et des changements sociaux. Si, d'un côté, il décrit les contextes des différentes époques du pays, il en subit simultanément l'influence, ce qui explique ses constantes mutations. Le sexisme à l'égard du football féminin, énoncé par des termes tels que « muses » ou « bombasses », a ainsi marqué l'histoire du magazine, dans ses versions Placar Mais (1984), Placar Todos os Esportes (1988) et Futebol, Sexo \& Rock and Roll (1995 à 1999). Avec l'avènement du féminisme, ces termes ont non seulement été écartés, mais le magazine a été jusqu’à publier, en 2019, des excuses pour son passé misogyne et sexiste. Cette imbrication historique s'observe également lorsque le magazine donne la parole à des joueurs qui n'hésitent pas à donner leurs opinions, qu'elles soient politiques (dans le contexte effervescent de la redémocratisation du pays, au moment des premières élections directes après la dictature militaire, les «Diretas Já ») ou dans le cadre des discussions autour de la professionnalisation du football brésilien et de la corruption dans le sport. Cette étude montre que seule une frontière ténue sépare l'histoire de la société brésilienne de celle de son football. À partir d'entretiens avec sept journalistes qui ont marqué les 
différentes phases du magazine (Celso Unzelte, Marcelo Duarte, Maurício Barros, Paulo Vinícius Coelho, Ricardo Corrêa, Sérgio Xavier Filho et le vétéran des rédacteurs, Juca Kfouri), cet article contribue à la construction historique d'un chapitre important de l'entrelacement de la culture sportive et sociale au Brésil. Cette relation est ici mise en perspective à partir du magazine sportif Placar, personnage toujours vivant et fondamental de l'histoire du journalisme sportif brésilien.

Mots-clés : Journalisme sportif ; Magazine Placar ; Journalisme ; Histoire du journalisme sportif.

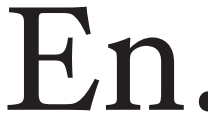

This article discusses the importance of Placar magazine in the construction of sports journalism in Brazil. It is based on the systematizaof different phases of the magazine and the great moments of its history. Placar is the oldest Brazilian sports magazine published and celebrated its jubilee in 2020, after fifty years of a continuous struggle to ensure its existence.

As an actor of the media sphere in Brazil, it has also been a catalyst of social yearnings and changes over the years. Therefore, it has always been in a process of mutation, describing them and, in parallel, being influenced by the social and political contexts. Sexism towards women in soccer, expressed by the use of terms such as «muses» or «hotties», is a part of the magazine's history, more specifically during the time of Placar Mais (1984), Placar Todos os Esportes (1988) and Futebol, Sexo \& Rock and Roll (1995 to 1999).

With the rise of feminist movements, these terms were discarded, and the magazine took a stand in 2019 by apologizing for the misogynistic and sexist content published in the past. Content imbued with historical momentums also appears at times when the magazine features players who voice political opinions (for instance during the effervescence of the context of redemocratization, at the time of the first direct elections after the fall of the military dictatorship, the so-called «Diretas Já») or share opinions on the professionalization of Brazilian soccer and the corruption operating within the sport's institutions. The study highlights how fine is the line between the history of Brazilian society and the history of Brazilian soccer. Based on interviews with seven journalists who contributed to the magazine during different phases of its existence (Celso Unzelte, Marcelo Duarte, Maurício Barros, Paulo Vinícius Coelho, Ricardo Corrêa, Sérgio Xavier Filho and the veteran editor, Juca Kfouri), the article contributes to the historical construction of an important testimony of the intertwining of sports and social history in Brazil. This relationship is illustrated through the history of Placar, shown as a contemporary and central player in the history of Brazilian sports journalism.

Keywords : Sports journalism; Placar magazine; Journalism; History of sports journalism.

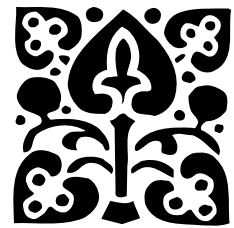

